\title{
Implementasi pendidikan karakter melalui pembelajaran pendidikan Pancasila dan kewarganegaraan di sekolah berbasis pesantren
}

\author{
Yuni Niki Lestari \\ Universitas Negeri Yogyakarta, Indonesia \\ Email: yuni.niki2015@student.uny.ac.id \\ Marzuki Marzuki \\ Universitas Negeri Yogyakarta, Indonesia \\ Email:marzuki@uny.ac.id
}

\begin{abstract}
Abstrak
Penelitian ini bertujuan untuk mendeskripsikan implementasi pendidikan karakter, mengidentifikasi faktor-faktor yang mempengaruhi dan menganalisis solusi yang tepat untuk mengatasi kendala implementasi pendidikan karakter melalui pembelajaran Pendidikan Pancasila dan Kewarganegaraan pada siswa di sekolah berbasis pesantren. Jenis penelitian ini adalah penelitian deskriptif dengan menggunakan pendekatan kualitatif. Penentuan subjek penelitian ini dengan purposive. Pengumpulan data menggunakan teknik observasi nonpartisipan, wawancara, dan dokumentasi. Pemeriksaan keabsahan data menggunakan triangulasi. Analisis data yang digunakan adalah analisis data model interaktif Miles dan Huberman dengan tahapan reduksi data, display data dan penarikan simpulan. Hasil penelitian menunjukkan bahwa: (1)
\end{abstract}


implementasi pendidikan karakter melalui pembelajaran Pendidikan Pancasila dan Kewarganegaraan melalui tiga tahap, yaitu perencanaan, pelaksanaan, dan evaluasi; (2) faktor-faktor pendukung pendidikan karakter di antaranya lingkungan pondok pesantren, pendidik mayoritas alumni pondok pesantren, dan kegiatan ektrakurikuler pramuka, sedangkan factor-faktor penghambatnya di antaranya karakter santri yang berbeda-beda, jarak antara asrama santri putra dan madrasah yang begitu jauh sehingga guru tidak bisa berkomunikasi secara langsung, dan durasi pembelajaran yang sedikit. (3) Solusi yang dilakukan di antaranya mengoptimalisasikan sistem poin ketika ada santri yang melanggar yaitu 25 poin sebagai peringatan, 50 poin sebagai teguran, koordinasi serta bekerja sama antara madrasah dan asrama.

Kata kunci: Implementasi Pendidikan Karakter, Sekolah Berbasis Pesantren, Pembelajaran PPKn.

\section{Abstract}

The purposes of this research are to describe the implementation of character education, identifying the affected factors and to analyze the right solution to solve the problem in the implementation of character education through the learning process of Civic and Pancasila Education for the students of Islamic boarding (pesantren) based school. This research is a descriptive qualitative research. The selection of the research subject is used by purposive technique. The data collection of the research is used by non-participant observation, interview and documentation. The validity of the research is used by triangulation. The data analysis process is based on the interactive model proposed by Miles and Huberman which include the data reduction, data display and drawing conclusion. The results showed that; (1) The implementation of character education through the learning process of Civic and Pancasila Education is through three phases namely plan, action and evaluation; (2) The supporting factors for character education include the boarding school environment of the islamic boarding school, the majority of teachers are alumni of the Islamic boarding school, and scout extracurriculer activity, while the inhibiting factors include the different characteristics of the santri, the distance between the santri male dormitory and the madrasah which is so far that the teacher cannot communicate directly, and the learning duration is small; (3) the possible solutions that will optimalize the learning results are the point system; when the students breaking the rules is 25 points as a warning and 50 points to reprimand 
the students, and the coordination and cooperation between madrasah and the boarding house.

Keywords: The Implementation of Character Education, Pesantren Based School, The Learning of Civic and Pancasila Education.

\section{Pendahuluan}

Pendidikan memiliki tujuan untuk mencapai proses melalui penciptaan suasana belajar dan proses pembelajaran. Adanya proses yang dicapai terdapat nilai yang diyakini kebenarannya sebagai dasar aktivitas serta mengembangkan segenap potensi internal individu anak. Puncak ketercapaian tujuan ini adalah kedewasaan, baik secara fisik, psikologik, sosial, emosial, ekonomi, moral, dan spiritual peserta didik (Rohman, 2009: 10).

Fungsi dan tujuan Pendidikan menurut Undang-Undang No. 20 Tahun 2003 tentang Sistem Pendidikan Nasional menegaskan pendidikan di Indonesia mengembangkan kemampuan dan membentuk watak serta peradaban bangsa yang bermartabat dalam rangka mencerdaskan kehidupan bangsa, tujuannya untuk mengembangkan potensi peserta didik agar menjadi manusia yang beriman dan bertaqwa kepada Tuhan Yang Maha Esa, berakhlak mulia, sehat, berilmu, cakap, kreatif, mandiri dan menjadi warga negara yang demokratis serta tanggung jawab.

Proses pendidikan tidak lepas untuk pembangunan pendidikan karakter. Pendidikan Pancasila dan Kewarganegaraan di Indonesia yang berbasis Pancasila merupakan pendidikan kebangsaan dan kewarganegaraan yang berkeberadaan NKRI, demokrasi, HAM, serta cita-cita untuk mewujudkan masyarakat madani dengan menggunakan filsafat Pancasila (Erwin, 2013: 3). Pendidikan Pancasila dan Kewarganegaraan sebagai wahana pendidikan karakter di Indonesia.

Pendidikan karakter sebuah proses transformasi nilai-nilai kehidupan untuk menumbuhkembangkan kepribadian seseorang sehingga menjadi satu dalam kehidupan (Gaffar, 2010: 1). Pendidikan karakter memfokuskan dalam pengembangan pendidikan yang menanamkan dan mengembangkan karakterkarakter luhur peserta didik (Husnaini, Victorynie, \& Amili, 2020). Pentingnya pendidikan karakter berdasarkan nilai-nilai pancasila perlu dimasukkan dan dikembangkan melalui pendidikan formal di sekolah khususnya pada Sekolah Menengah Pertama berbasis pondok pesantren (Murdiono dkk, 2017: 427. Benaziria, \& Murdiono, 2019). 
Sekolah berbasis pesantren memiliki cara tersendiri dalam untuk melaksanakan pendidikan karakter. Kehadiran pesantren termasuk lembaga tertua di Indonesia. Keberadaan pesantren sebagai lembaga pendidikan Islam di tanah air memiliki andil yang cukup besar dalam pembentukan karakter bangsa Indonesia. Perpaduan antara pendidikan umum dan pesantren akan melahirnya sistem pendidikan Islam yang konprehensif. Pembaharuan tersebut ditandai dengan lahirnya madrasah. Inovasi baru dengan adanya pesantren membentuk lembaga madrasah tersebut dipengaruhi oleh respons pendidikan Islam terhadap pendidikan kolonial Belanda sebagai akibat politik etis dan adanya gerakan pembaharuan Islam di Indonesia (Qamar, 2007: 91).

Pesantren mengalami perkembangan yang sangat pesat. Berdasarkan klasifikasi sistem pengajaran berbasis pesantren ada dua yakni modern dan tradisional. Pesantren tradisional saat ini sudah memfasilitasi sekolah formal dalam pendidikan pesantren. Sistem pendidikan pesantren mulai akrab dengan metode ilmiah sehingga lebih terbuka sebagai program dan kegiatan sebagai pusat pengembangan masyarakat.

Pondok pesantren yang dimaksud dalam penelitian ini yakni pondok pesantren Assalafiyyah yang berada di Kampung Islam Mlangi, Sleman, Yogyakarta yang terletak di Desa Nogotirto Kecamatan Gamping kabupaten Sleman Yogyakarta. Keberadaan kampung santri ini terdiri dari 17 pondok pesantren. Pondok Assalafiyyah termasuk pondok pesantren salaf yang masih mempertahankan gaya tradisional yang masih eksis hingga kini karena adanya peran kiai sebagai penetu kebijakan di pesantren, kedua keberadaan nilai-nilai keberkahan yang selalu dipertahankan dan nilai hormat dan patuh terhadap kiai, ketiga kurikulum pesantren salaf yang dianggap dapat membuat santri menguasai ilmu-ilmu keagamaan secara luas, keempat kepercayaan masyarakat terhadap pesantren salaf. Hingga saat ini masyarakat masih mempercayai dan sangat menghormatu tokoh-tokoh pendiri pesantren salaf dan keluarganya (Shofiyyah, Ali, \& Sastraatmana. 2019: 11). Pondok pesantren tradisional memiliki ciri seperti halnya pesantren pada umumnya yang memiliki prinsip utama kegiatan di sekolah pesantren adalah nilai-nilai Quran dan Hadis (Sista $\mathrm{dkk}, 2019:$ 14).

Pendidikan karakter yang dilaksanakan di MTs Assalafiyyah Mlangi, Sleman, Yogyakarta melalui pembelajaran Pendidikan Pancasila dan Kewarganegaraan yang berbasis pesantren merupakan madrasah yang menandakan bahwa untuk menanamkan pendidikan karakter yang dinilai efektif oleh berbagai kalangan yakni model madrasah yang diperkuat oleh sistem 
pondok pesantren (Boarding School) yang tidak hanya memberikan pengetahuan kepada santri dari aspek kognitif saja melainkan secara kolektif membiasakan budaya yang berpijak pada ilmu dalam pengetahuan sehari-hari.

Penanaman pendidikan karakter di pesantren diintegrasikan melalui pembelajaran di semua mata pelajaran. Pembelajaran Pendidikan Pancasila dan Kewarganegaraan memiliki peran yang penting untuk hadir guna untuk menselaraskan Islam dan negara di sekolah berbasis pesantren. Peran pembelajaran Pendidikan Pancasila dan Kewarganegaraan yang mengembangkan karakter kewarganegaraan peserta didik.

Hadirnya pembelajaran Pancasila dan Kewarganegaraan di sekolah berbasis pondok pesantren memiliki hubungan yang erat kerena Pendidikan Pancasila dan Kewarganegaraan dengan karakter kewarganegaraan dalam hal ini pendidikan berbasis pesantren harus mampu mendukung upaya pengembangan karakter peserta didik untuk menjadi warga negara yang baik meskipun pesantren kuat dengan nilai-nilai keIslamannya.

Penananman karakter pada pembelajaran Pendidikan Pancasila dan Kewarganegaraan masih mengalami permasalahan. Karakter santri putra dan santri putri yang memiliki perbedaan sehingga guru masih mengalami kesusahan dalan menanamkan karakter di dalam pembelajaran.

Karakter santri putra yang berbeda ketika di asrama dan di madrasah ini terlihat ketika peneliti melakukan pra-penelitian bulan Desember 2018 lalu ditemukan masih banyak siswa yang tidak disiplin dalam pembelajaran seperti ramai dikelas, tidak memperhatikan guru saat pelajaran, tidak disiplin dalam berpakaian. Ketika bel berbunyi siswa tidak segara masuk ke kelas melainkan masih ada yang bermain sepak bola di lapangan. Durasi pembelajaran yang sedikit karena kurikulum di MTs Assalafiyyah yang terintegrasi kurikulum kepesantrenan, kementerian agama, dan kementerian pendidikan nasional, sehingga guru Pendidikan Pancasila dan Kewarganegaraan merasa terkendala dalam penanaman pendidikan karakter yang pembelajarannya hanya berlangsung 1 jam pelajaran yang berdurasi 45 menit.

Kajian yang diangkat dari penelitian yang berjenis kualitatif bertujuan untuk mendeskripsikan implementasi pendidikan karakter, mengidentifikasi faktor-faktor yang mempengaruhi dan menganalisis solusi yang tepat untuk mengatasi kendala implementasi pendidikan karakter melalui pembelajaran Pendidikan Pancasila dan Kewarganegaraan pada siswa di MTs Assalafiyyah Mlangi, Sleman, Yogyakarta. 


\section{Metode Penelitian}

Penelitian ini merupakan penelitian deskriptif dengan menggunakan pendekatan kualitatif. Penelitian ini dilaksanakan di MTs Assalafiyyah Mlangi, Sleman, Yogyakarta yang merupakan sekolah berbasis pesantren dan berbasis alam, penelitian ini dilaksanakan pada bulan Februari-Juli 2019. Penentuan subjek penelitian ini dengan cara purpossive yaitu teknik pengambilan data dengan pertimbangan tertentu dan tujuan tertentu (Prastowo, 2012: 197). Subjek penelitian ini yaitu Kepala Sekolah, Waka Kurikulum, Guru Pamong Pendidikan Pancasila dan Kewarganegaraan, dan santri putra dan putri kelas VII, VIII, IX MTs Assalafiyyah Mlangi, Sleman, Yogyakarta. Data penelitian diperoleh melalui observasi, wawancara, dan dokumentasi. Pemeriksaan keabsahan data menggunakan triangulasi. Analisis data menggunakan teknik analisis data interaktif model Miles dan Huberman dengan langkah-langkah reduksi data, display data, dan penarikan simpulan.

\section{Hasil Penelitian Dan Pembahasan}

\section{Implementasi Pendidikan Karakter melalui Pembelajaran PPKn}

Pelaksanaan pendidikan karakter melalui pembelajaran Pendidikan Pancasila dan Kewarganegaraan (PPKn) dilakukan melalui beberapa tahapan, yaitu perencanaan, pelaksanaan, dan evaluasi. Pada tahap perencanaan pendidikan karakter melalui Pembelajaran Pendidikan Pancasila dan Kewarganegaraan, dilaksanakan dengan merencanakan tujuan sekolah berkaitan dengan pendidikan karakter yakni tertuang dalam visinya mencetak anak didik yang berilmu dan berakhlak mulia. Penyelenggaraan pendidikan yang berintegritas dan berkualitas berbasis pesantren berlangsung dengan mengintegrasikan pembelajaran ilmu-ilmu akademis dan kepesantrenan.

Tujuan pendidikan tersebut selain menjadi ahli di bidang pengetahuan, juga memiliki akhlak yang baik (mulia). Peningkatan mutu proses dan hasil pendidikan yang mengarah pada pembentukan karakter dan ahklak mulia peserta didik yang utuh (Mulyasa, 2011: 9). Tujuan pendidikan karakter yang dicanangkan di MTs Assalafiyyah masih releven dengan tujuan tersebut yang menekankan pada pembentukan peserta didik yang berilmu dan berakhlak mulia serta berkulitas dengan mendasarkan pada nilai-nilai yang dikembangkan oleh pondok pesantren. 
Pengintegrasian pendidikan karakter dalam kurikulum untuk pembelajaran Pendidikan Pancasila dan Kewarganegaraan diintegrasikan melalui kurikulum 2013. Kurikulum merupakan ruh atau inti dari pendidikan (Wibowo, 2012: 71). Kurikulum yang digunakan di MTs Assalafiyyah, yakni kurikulum PPKn 2013, menjanjikan lahirnya generasi penerus bangsa yang produktif, kreatif, inovatif, dan berkarakter. Kurikulum PPKn 2013 lebih menekankan empat pilar kebangsaan (konsesus nasional) yang menjadi identitas bangsa Indonesia. Kurikulum MTs Assalafiyyah mengintegrasikan kurikulum kepesantrenan, kurikulum kementerian agama, dan kementerian pendidikan nasional. Pengintegrasian karakter diterapkan di semua mata pelajaran termasuk mata pelajaran Pendidikan Pancasila dan Kewarganegaraan.

\section{Perencanaan dalam Kegiatan Pembelajaran PPKn}

Wibowo (2012: 36) berpendapat bahwa pendidikan memiliki posisi yang penting untuk menanamkan serta mengembangkan karakter kepada siswa sehingga siswa bisa mempraktikkannya di lingkungan masyarakat. Mengenai pembelajaran Pendidikan Pancasila dan Kewarganagaraaan sebagai pendidikan karakter tentu peran guru sangatlah penting untuk membimbing dan mendidik agar siswa memiliki karakter yang baik.

Pendidikan Pancasila dan Kewarganegaraan dengan berbagai makna yang beragam memiliki tujuan untuk membangun karakter (character building) bangsa Indonesia guna menjaga persatuan dan integritas bangsa (Ubaidilah, 2015: 18).

Hasil penelitian menunjukkan bahwa perencanaan penanaman karakter melalui pembelajaran Pendidikan Pancasila dan Kewarganegaraan dilakukan dengan mencantumkan beberapa karakter yang ditargetkan agar terimplementasi. Karakter yang dicantumkan yaitu religius, jujur, disiplin, rasa ingin tahu, peduli lingkungan, demokratis, dan semangat kebangsaan.

Karakter merupakan istilah baru yang digunakan dalam wacana Indonesia untuk beberapa tahun terakhir. Istilah ini sering dihubungkan dengan dua istilah sebelumnya yakni etika dan moral, bahkan juga terkait dengan istilah akhlak dan nilai. Karakter juga sering dikaitkan dengan masalah kepribadian atau paling tidak ada hubungan yang cukup erat antara karakter dan kepribadian seseorang (Marzuki, 2015: 18). Pendidikan karakter melalui pembelajaran Pendidikan Pancasila dan Kewarganegaraan sudah terlaksana cukup baik. Penanaman karakter yang menonjol di MTs Assalafiyyah yakni karakter religius, jujur, disiplin, rasa ingin tahu, peduli lingkungan, demokratis dan semangat kebangsaan. Selanjutnya karakter-karakter ini dijelaskan sebagai 
berikut.

Karakter religius; mencerminkan sikap dan perilaku yang dekat dengan hal-hal spiritual (Kurniawan, 2013: 128). Seseorang dapat dikatakan memiliki sikap religius jika ia merasa perlu dan berusaha mendekatkan dirinya dengan Tuhan (sebagai penciptanya) dan patuh melaksanakan ajaran agama yang dianutnya. MTs Assalafiyyah, Mlangi, Sleman, Yogyakarta merupakan sekolah berbasis pondok pesantren yang mengedepankan pendidikan Islam, sehingga dalam implmentasi karakter religius lebih diutamakan. Penguatan karakter religius melalui pembelajaran Pendidikan Pancasila dan Kewarganegaraan dengan cara memulai dan mengakhiri pembelajaran dengan berdoa, kemudian dilanjutkan melantunkan al-asmaul husna secara bersama-sama, dan melakukan ziarah. Berdasarkan pengamatan yang dilakukan peneliti dari tanggal 27 Maret-02 April 2019 terlihat bahwa kegiatan tersebut sudah berjalan dengan baik. Hal ini, dibuktikan ketika bel berbunyi siswa memasuki kelas masingmasing kemudian berdoa secara bersama-sama. Kegiatan menghafal al-asmaul husna dilaksanakan hanya pada jam pertama saat pembelajaran yang berlangsung setiap hari dan untuk jam kedua dan berikutnya hanya membaca al fatihah secara bersama-sama.

Karakter kejujuran merupakan karakter penting yang harus dimiliki setiap orang. Jujur tidak hanya diucapkan, namun harus tercermin dalam perilaku sehari-hari (Naim, 2012: 132). Menumbuhkan sikap jujur sebagai karakter sangat penting karena saat ini kejujuran semakin terkikis.

Penguatan karakter jujur melalui pembelajaran Pendidikan Pancasila dan Kewarganegaraan terlihat ketika peneliti melakukan pengamatan di kelas VIII B pada materi Sumpah Pemuda, dan organisasi pemuda guru memberikan kuis yang terdiri dari 5 soal kepada siswa untuk melatih untuk menerapkan sikap jujur agar siswa mengerjakan dengan sungguh-sungguh dan dikerjakan dengan secara mandiri. Guru memberikan keluasan waktu selama 20 menit guna memberikan waktu untuk mengerjakan. Dari hal ini, tampak penanaman nilai kejujuran yang sangat tinggi dan ini harus mendapatkan bimbingan secara berkala.

Karakter kedisiplinan mencerminkan kehidupan suatu masyarakat atau bangsa. Karakter disiplin sangat ditekankan dalam kehidupan sehari-hari guna untuk meraih suatu keberhasilan dari setiap usaha yang dilakukan baik dalam menepati waktu, jadwal pekerjaan serta mengikuti semua yang sudah digariskan (Marzuki, 2009: 213-214). Karakter disiplin ini sudah diterapkan oleh guru pamong Pendidikan Pancasila dan Kewarganagaraan di kelas IX A 
MTs Assalafiyyah Mlagngi. Guru mengupayakan kedisiplinan dengan mengajak siswa untuk mematuhi segala peraturan khususnya ketika pembelajaran berlangsung. Guru mengajak siswa agar selalu datang ke sekolah tepat waktu dan tidak boleh datang terlambat. Materi yang disampaikan ketika observasi di kelas IX A mengenai pendalaman soal dari materi kelas VII, VIII, dan IX. Di sini nilai kepatuhan dan ketaatan ditanamkan oleh guru pamong PPKn kepada siswa agar ia mengingat-ingat materi yang sudah diberikan agar nantinya siswa bisa menjawab soal ketika mengikuti ujian kelulusan.

Terkait dengan karakter rasa ingin tahu, ada empat alasan yang mendasari pentingnya rasa ingin tahu bagi siswa, yakni rasa ingin tahu membuat pikiran siswa menjadi aktif, rasa ingin tahu membuat siswa menjadi pengamat yang aktif, rasa ingin tahu akan membuka dunia-dunia baru yang menantang dan manarik siswa untuk mempelajari lebih dalam, dan rasa ingin tahu membawa kejutan-kejutan kepuasan dalam diri siswa dan meniadakan rasa bosan untuk belajar (Kurniawan (2013: 148).

Hasil penelitian menunjukkan bahwa karakter rasa ingin tahu siswa di MTs Assalafiyyah Mlangi masih cukup tinggi, yang dibuktikan dengan adanya media pembelajaran baru berupa TAB di semester genap. Hal ini membuat semangat belajar siswa menjadi bertambah. Fasilitas yang ada di dalam TAB juga disertai dengan kuis sehingga siswa bisa lebih tertarik dalam belajar PPKn.

Guru pamong Pendidikan Pancasila dan Kewarganegaraan dalam menerapkan karakter rasa ingin tahu ini terlihat ketika peniliti melakukan observasi pada kelas VIII C pada materi peran perjuangan pemuda dalam organisasi pemuda. Guru membimbing siswa untuk mencari tahu latar belakang tokoh-tokoh pemuda dalam organisasi kepemudaan dan mengambil hikmah serta perjuangan dari tokoh-tokoh tersebut seperti Muhammad Tabrani sebagai tokoh sekaligus ketua dalam konggres pemuda 1 .

Karakter peduli lingkungan siswa dapat dijelaskan melalui kepeduliannya pada lingkungan yang terbentuk melalui budaya sekolah yang kondusif. Budaya sekolah yang kondusif merupakan keseluruhan latar fisik lingkungan, suasana, rasa, sifat, dan iklim sekolah yang secara produktif mampu memberikan pengalaman baik bagi tumbuh kembangnya karakter peserta didik yang diharapkan (Kurniawan, 2013: 156).

Hasil penelitian menunjukkan rasa kepedulian lingkungan yang dimiliki siswa masih kurang. Hal ini ditunjukkan ketika guru pamong Pendidikan Pancasila dan Kewarganegaraan masuk kelas masih terdapat sampah berserakan 
di dalam kelas khususnya santri putra yang masih belum memiliki kesadaran diri dalam menjaga kebersihan kelas. Berbeda halnya ketika masuk ke kelas, santri putri terlihat bersih saat pembelajaran berlangsung. Sekolah telah berupaya ketika waktu istirahat selalu ada peringatan untuk selalu membuang sampah pada tempatnya. Guru memberikan arahan kepada siswa bahwa siswa memiliki hak dan tanggung jawab untuk membersihkan kelas untuk menciptakan suasana kelas yang nyaman.

Kegiatan yang mendukung siswa menumbuhkan karakter peduli lingkungan telah dilaksanakan melalui kerja bakti ketika sepulang sekolah dan terjadwal dengan tertib. Selain itu, kerja bakti yang dilaksanakan semua santri putra dan santri putri dilaksanakan setiap hari Kamis ketika kegiatan ekstrakurikuler.

Karakter demokratis juga sangat ditekankan di MTs Assalafiyyah Mlangi. Prinsip yang dikembangkan yaitu menumbuhkembangkan spirit demokrasi di kalangan siswa dengan cara: menghormati pendapat orang lain, berbaik sangka terhadap pendapat orang lain, dan sikap fair terhadap pendapat orang lain (Naim, 2012: 168). Nilai-nilai demokratis ini dipercaya akan membawa kehidupan berbangsa dan bernegara dalam semangat egalitarian dibandingkan dengan ideologi nondemokratis.

Hasil penelitian menunjukkan bahwa ketika pembelajaran di kelas siswa berpikir kritis yang ditunjukkan dengan proses dialog interaktif antara guru dan siswa. Penanaman karakter demokratis di MTs Assalafiyyah cukup baik. Hal ini terlihat ketika peneliti melakukan observasi di kelas pada 01 April 2019 pada pembelajaran Pendidikan Pancasila dan Kewarganegaraan di kelas VII F. Dalam penyampaian pendapat masing-masing santri melakukannya dengan cukup baik. Hal ini terlihat ketika guru menyampaikan materi perjuangan menuju Negara Kesatuan Republik Indonesia (NKRI) siswa sangat antusias dalam mengajukan pendapatnya. Kegiatan yang lain yang melibatkan seluruh siswa yakni adanya pemilihan ketua osis yang sudah berjalan cukup baik di MTs Assalafiyyah ini. Begitu juga semua siswa turut andil dalam pemilos (pemilihan osis) di MTs Assalafiyyah Mlangi ini.

Karakter semangat kebangsaan dapat diperhatikan pada indikator memiliki keterikatan emosional siswa dengan negara sebagai wujud rasa bangga dan memiliki bangsa dan negara. Perasaan bangga dan memiliki terhadap bangsanya akan mampu melahirkan sikap rela berkorban untuk memperoleh dan mempertahankan kemerdekaan serta kedaulatan negara (Kurniawan, 2013: 149). 
Penanaman dan penguatan karakter semangat kebangsaan di MTs Assalafiyyah cukup baik. Hal ini terlihat ketika pembelajaran Pendidikan Pancasila dan Kewarganegaraan di kelas VIII B mengenai materi Daerah dalam NKRI. Pada pembelajaran itu guru menanamkan karakter semangat kebangsaan dengan penegasan bahwa dalam meraih apa yang didapatkan untuk menuju kemerdekaan itu sangatlah tidak mudah. Kemerdekan ini terjadi melalui proses panjang. Pada saat menjelang kemerdekaan dibentuk lembaga yang mempersiapkan proses kemerdekaan seperti BPUPKI dan PPKI. Melalui dua lembaga ini para pendiri bangsa (Soekarno dkk) mengadakan sidang-sidang sampai akhirnya terwujud kemerdekaan pada tanggal 17 Agustus 1945. Hal ini merupakan sikap yang ditanamkan guru pamong PPKn untuk menerapkan sikap semangat kebangsaan kepada siswa dengan mengajarkan arti semangat juang khususnya sebagai generasi muda.

Kegiatan lain yang mendukung karakter semangat kebangsaan di MTs Assalafiyyn yaitu setelah bel berbunyi tanda pulang sekolah diperdengarkan lagu-lagu kebangsaan dan lagu-lagu nasional. Yang lebih penting lagi untuk menanamkan semangat kebangsaan kepada siswa, setiap bulan sekali, tepatnya tanggal 17, diadakan upacara bendera yang diikuti oleh seluruh komponen sekolah, terutama siswa.

\section{Pelaksanaan Pendidikan Karakter dalam Pembelajaran PPKn}

Pelaksanaan pendidikan karakter di MTs Assalafiyyah Mlangi, Sleman, Yogyakarta dengan berpedoman pada kurikulum 2013 yang mengharuskan guru mencantumkan nilai-nilai karakter di dalam Rencana Pelaksanaan Pembelajaran (RPP) dan Silabus. Pelaksanaaan proses kegiatan pembelajaran Pendidikan Pancasila dan Kewargamegaraan di MTs Assalafiyyah Mlangi pada umumnya terdiri atas tiga tahap kegiatan, yaitu kegiatan pendahuluan, kegiatan inti, dan kegiatan penutup. Ketiga tahap kegiatan pembelajaran tersebut dilaksanakan agar peserta didik mempraktikkan nilai-nilai karakter yang ditargetkan oleh guru. Secara detail tentang tiga tahap kegiatan pembelajaran ini dapat dijelaskan sebagai berikut.

1. Kegiatan Pendahuluan

Berdasarkan observasi selama dua minggu di 8 kelas di MTs Assalafiyyah Mlangi, yakni observasi di kelas VII A, VII B, VII C, VII E, VII F, VIII A, VIII B, VIII C, VIII D, dan IX A, pada bulan Maret 2019 terlihat bahwa kegiatan pendahuluan dalam pembelajaran Pendidikan Pancasila dan Kewarganegaraan yang dilakukan guru hampir sama, yakni 
guru menyiapkan peserta didik secara psikis dan fisik untuk mengikuti pembelajaran yang akan berlangsung. Apabila kelas masih dalam kondisi kotor maka guru langsung menegur untuk segera dibersihkan agar proses pembelajaran berlangsung secara khidmat. Selain itu, guru meminta siswa untuk maju ke depan kelas untuk memimpin doa baik sebelum proses pembelajaran berlangsung maupun setelah proses pembelajaran berakhir. Setelah doa pembuka kegiatan berdoa dilanjutkan dengan menghafal asmaul husna secara bersama-sama. Untuk pelaksanaan menghafal asmaul husna hanya dilakukan pada jam pertama berlangsung, dan jika sudah memasuki jam kedua dan seterusnya hanya cukup dengan membaca surat al-Fatihah saja. Selanjutnya guru mengucapkan salam yang dilanjut dengan melakukan presensi kehadiran. Lalu guru memberikan motivasi kepada siswa agar lebih semangat dalam belajar berlangsung.

Pada tahap selanjutnya guru membagikan media TAB kepada siswa satu persatu untuk mengganti buku cetak yang baru berjalan di semester genap ini dan memberika apersepsi kepada siswa sebelum pembelajaran dimulai. Guru selanjutnya menyampaikan tema dan materi yang akan dikaji pada proses pembelajaran. Guru juga memberi tahu tentang kompetensi inti, kompetensi dasar, indikator, dan KKM kepada siswa. Kegiatan pendahuluan ini diakhiri dengan penyampaian cakupan materi dan uraian kegiatan sesuai dengan silabus.

Sejumlah cara ditempuh untuk mengamalkan nilai-nilai membangun kepedulian dan membantu internalisasi nilai atau karakter pada tahap pembelajaran berlangsung. Dari kegiatan pembelajaran di atas guru berusaha menamankan sikap disiplin yakni masuk ke kelas dengan tepat waktu, berdoa sebelum membuka pembelajaran. Dengan kegiatankegiatan ini guru telah menanmkan nilai religius dan disiplin kepada siswa. Guru melakukan apersepsi untuk menanamkan karakter rasa ingin tahu. Guru memberikan arahan untuk membersihkan ruangan kelas untuk menanamkan nilai peduli lingkungan. Dengan demikian, dapat disimpulkan bahwa kegiatan pendahuluan dalam pembelajaran sudah sesuai dengan Rencana Pelaksanaan Pembelajaran (RPP) yang dibuat oleh guru pamong Pendidikan Pancasila dan Kewarganegaraan.

2. Kegiatan Inti

Berdasarkan observasi di kelas kelas VII F tanggal 1 April 2019 pada saat pembelajaran PPKn tentang materi Daerah dalam Kerangka Negara Kesatuan Republik Indonesia (NKRI) dapat dijelaskan sebagai berikut. 
Guru meminta siswa untuk membuka media TAB dengan materi Daerah dalam kerangka Negara Kesatuan Republik Indonesia (NKRI) tersebut. Guru meminta siswa untuk membaca materi perjuangan menuju NKRI dan guru meminta siswa untuk membandingkan era kebangkitan nasional saat dibentuknya BPUPKI dan PPKI dengan waktu-waktu sebelumnya. Untuk hal ini guru membagi siswa menjadi beberapa kelompok untuk mendiskusikan tema-tema terkait dengan era kebangkitan 20 Mei 1928, era kebangkitan dengan terbentuknya BPUPKI dan PPKI, dan tokohtokoh yang berperan dalam kebangkitan tersebut. Setelah selesai berdiskusi dalam kelompok masing-masing, guru meminta satu persatu kelompok maju untuk mempresentasikan hasil diskusinya ditanggapi oleh kelompokkelompok yang lain. Secara bergiliran presentasi dilakukan oleh setiap kelompok sampai selesai. Di setiap presentasi guru meminta ada minimal satu pertanyaan dari kelompok yang tidak presentasi. Pada saat diskusi berlangsung guru mengontrol dan mengawasi proses diskusi dan gerak-gerik siswa. Di akhir diskusi guru meminta semua kelompok mengumpulkan lembar kertas hasil diskusi.

Berdasarkan kegiatan inti dapat dipahami bahwa guru telah melaksanakan kegiatan pembelajaran yang menanamkan karakter dengan baik. Hal ini tampak pada penanaman sikap demokratis pada saat diskusi kelompok berlangsung. Upaya guru meminta setiap perwakilan kelompok untuk membuat pertanyaan bertujuan untuk menanamkan rasa ingin tahu kepada siswa. Guru meminta setiap kelompok untuk mengumpulkan hasil kerja diskusi bertujuan untuk menanamkan sikap jujur kepada siswa.

3. Kegiatan Penutup

Untuk kegiatan penutup, tahapan kegiatan yang dilakukan dalam pembelajaran antara lain guru bersama-sama dengan siswa atau sencara mandiri membuat rangkuman/simpulan hasil pembelajaran. Pada tahap ini guru berusaha menanamkan nilai rasa ingin tahu, demokratis, dan semangat kebangsaan. Kemudian guru melakukan penilaian dan refleksi terhadap kegiatan yang sudah dilaksanakan secara konsisten dan terprogram. Melalui tahapan ini guru menanamkan nilai jujur dan mengetahui kelebihan dan kekurangan siswa. Guru selanjutnya merencanakan tindak lanjut pembelajaran dalam bentuk pembelajaran remedial, program pengayaan, layanan konseling, memberikan tugas individual atau kelompok sesuai dengan hasil belajar, dan menyampaikan rencana pembelajaran pada pertemuan berikutnya. Akhirnya guru menutup pembelajaran dengan 
berdoa dan salam. Melalui tahap ini guru sudah menanamkan nilai religius kepada siswa.

\section{Penilaian dalam Pembelajaran PPKn}

Penilaian merupakan aspek penting dalam proses pendidikan karakter, terutama dalam pembelajaran Pendidikan Pancasila dan Kewarganegaraan. Penilaian dilakukan untuk mengetahui apakah pembelajaran yang dilakukan berhasil atau tidak. Dengan penilaian ini sebagian besar siswa dapat membentuk kompetensi dan karakter yang diharapkan secara optimal, karena banyak siswa mendapat nilai rendah atau berkarakter tidak sesuai dengan norma kehidupan. Hal ini akan mempengaruhi efektivitas pendidikan karakter secara keseluruhan (Mulyasa, 2016: 192). Penilaian karakter yang dilakukan guru pamong pada pembelajaran Pendidikan Pancasila dan Kewarganegaraan di MTs Assalafiyyah Mlangi menggunakan pengamatan secara langsung di kelas dan di luar kelas. Penggunaan sistem poin sangat dominan dalam penilaian pendidikan karakter. Hal ini dapat dilihat dalam Rencana Pelaksanaan Pembelajaran Pendidikan Pancasila dan Kewarganegaraan yang dibuat guru pamong. Guru menggunakan jurnal sebagai instrumen penilaian sikap atau karakter siswa di kelas.

\section{Faktor-Faktor yang Mempengaruhi Implementasi Pendidikan Karakter Berbasis Pesantren melalui pembelajaran PPKn}

\section{Faktor Pendukung}

Terdapat beberapa faktor yang mendukung implementasi pendidikan karakter berbasis pondok pesantren melalui pembelajaran Pendidikan Pancasila dan Kewarganegaraan di MTs Assalafiyyah Mlangi, Sleman, Yogyakarta, di antaranya sebagai berikut.

a. Tempat tinggal santri MTs Assalafiyyah yang berada di pesantren

Faktor pendukung utama dari implementasi pendidikan karakter di MTs Assalafiyyah Mlangi, Sleman, Yogyakarta yaitu keberadaan siswa yang tinggal di pesantren. Semua siswa di MTs ini diwajibkan untuk bermukim di asrama (pesantren) dan tidak boleh ada yang tinggal di luar pesantren. Untuk hal ini ada kerja sama antara pengelola madrasah dengan pengurus asrama dengan baik untuk kelancaran dalam menjalankan kurikulum kepesantrenan dan kurikulum pendidikan nasional.

Pendidik mayoritas alumni pondok pesantren 
Faktor kedua dari pendukung implementasi pendidikan karakter yakni mayoritas tenaga pendidik di MTs Assalafiyah Mlangi alumni pondok pesantren. Dengan latar belakang pesantren ini saat pembelajaran berlangsung pendidik secara otomatis mengajarkan keteladanan kepada semua siswa.

b. Kegiatan ektrakurikuler pramuka

Kegiatan ektrakurikuler di MTs Assalafiyyah Mlangi dilakukan setiap hari Kamis baik untuk siswa laki-laki maupun untuk siswa perempuan. Kegiatan pembelajaran di hari Kamis ditiadakan dan diisi dengan kegiatan ektrakurikuler. Kegiatan ekstrakurikuler yang membantu dalam pelaksanaan pendidikan karakter sebagaimana yang disampaikan guru pamong Pendidikan Pancasila dan Kewarganegaraan yakni ekstrakurikuler pramuka yang mengajarkan banyak kedisiplinan.

Kegiatan ekstrakurikuler sangat penting diadakan untuk penanaman dan penguatan pendidikan karakter kepada siswa. Pentingnya pendidikan karakter berdasarkan nilai-nilai Pancasila juga perlu dimasukkan dan dikembangkan di sekolah melalui pendidikan formal, khususnya di sekolah berbasis pesantren. Pengembangan karakter kebangsaan Pancasila diupayakan melalui integrasi pendidikan karakter dalam program intra dan ekstrakurikuler sekolah (Murdiono dkk, 2017: 423).

\section{Faktor Penghambat}

Faktor penghambat dari implementasi pendidikan pendidikan karakter berbasis pondok pesantren melalui pembelajaran Pendidikan Pancasila dan Kewarganegaraan di MTs Assalafiyyah Mlangi, Sleman, Yogyakarta di antaranya yaitu: 1) keberagaman karakter yang dimiliki oleh siswa (santri); 2) perbedaan karakter antara siswa laki-laki dan siswa perempuan; dan jauhnya jarak antara asrama putra dan madrasah sehingga mengganggu kelancaran siswa berkomunikasi secara cepat.

\section{Solusi untuk Mengatasi Kendala dalam Implementasi Pendidikan Karakter Berbasis Pesantren melalui Pembelajaran PPKn}

Ada beberapa solusi yang ditawarkan untuk mengatasi kendala implementasi pendidikan karakter melalui pembelajaran Pendidikan Pancasila dan Kewarganegaraan berbasis pesantren di antaranya sebagai berikut. 


\section{Mengoptimalisasikan sistem poin}

Sistem poin diterapkan ketika ada siswa yang melanggar peraturan di sekolah baik laki-laki maupun perempuan. Sistem poin akan berlaku dengan ketentuan yang disampaikan Kepala Sekolah yaitu dengan memberikan nominal poin total yang diperoleh siswa dengan poin 25 sebagai peringatan, dan poin 50 sebagai teguran. Dengan adanya sistem poin ini terjadi perubahan yang baik, yakni siswa yang melanggar peraturan sekolah semakin sedikit.

\section{Koordinasi dan bekerja sama antara madrasah dan asrama}

Hadirnya madrasah memberi harapan untuk penanaman pendidikan karakter kepada siswa. Hal ini dinilai efektif oleh berbagai kalangan, terutama dengan hadirnya model madrasah yang diperkuat oleh sistem pesantren (boarding school) yang tidak hanya memberikan pengetahuan kepada santri dari aspek kognitif saja melainkan secara kolektif membiasakan budaya berpijak pada ilmu dalam pengetahuan sehari-hari (Najib, 2018: 4).

Pendidikan karakter akan efektif jika memperhatikan komponenkomponen pokoknya, yakni moral knowing (pengetahuan moral), moral feeling (perasaan moral), dan moral action (perilaku moral). Jika semua komponen dan sub-sub komponen pendidikan karaker tersebut dimiliki seseorang, maka ia akan memiliki karakter yang baik (Miftahudiin \& Puji, 2018: 135). Oleh karena itu, pendidikan memiliki peran yang sangat penting di lingkungan asrama dan madrasah sehingga terdapat kerja sama yang baik untuk membimbing siswa ketika di asrama dan di madrasah. Peran guru sebagai agen perubahan pendidikan karakter nampaknya memiliki posisi yang sangat strategis, terutama sebagai teladan bagi siswa. Maka guru harus memiliki katakter yang baik yang menjadi teladan bagi siswanya.

\section{Penutup}

Berdasarkan hasil penelitian dan pembahasan, dapat disimpulkan bahwa implementasi pendidikan karakter melalui pembelajaran Pendidikan Pancasila dan Kewarganegaraan di MTs Assalafiyah dilaksanakan dalam tiga tahap, yakni perencanaan, pelaksanaan, dan penilaian. Faktor-faktor yang mempengaruhi implementasi pendidikan karakter melalui pembelajaran Pendidikan Pancasila dan Kewarganegaraan di MTs Assalafiyah ada dua macam, yaitu faktor pendukung dan faktor penghambat. Solusi yang bisa dipertimbangkan untuk mengatasi kendala implementasi pendidikan karakter melalui pembelajaran Pendidikan 
Pancasila dan Kewarganegaraan di MTs Assalafiyah mengoptimalisasikan yaitu sistem poin serta koordinasi dan bekerja sama antara pengelola madrasah dan pengurus asrama.

\section{Daftar Pustaka}

Benaziria, B., \& Murdiono, M. (2019). Civic teacher strategy in the integration of nationalism and tolerance character in school based on pesantren in Yogyakarta city. Journal of Social Studies (JSS), 15(1). 13-34

Erwin, M. (2013). Pendidikan kewarganegaraan republik Indonesia. Banduung: PT Refika Aditama.

Husnaini, M., Victorynie, I., \& Amili, N. (2020). Model of religious character education: A case study in Al-Hilal Islamic Primary School Bekasi, Indonesia. Journal of Social Studies (JSS), 16(2), 103-120.

Gaffar, M.F. (2010). Pendidikan karakter berbasis Islam. (Disampaikan pada workshop Pendidikan Karakter Berbasis Agama, 08-10 April 2010 di Yogyakarta).

Kurniawan, S. (2013). Pendidikan karakter konsepsi dan implementasinya secara terpadu di lingkungan keluarga, sekolah, perguruan tinggi dan masyarakat. Yogyakarta: Ar-Ruzz Media.

Marzuki. (2009). Prinsip dasar akhlak mulia. Pengantar studi konsep-konsep dasar etika dalam Islam. Yogyakarta: Debut Wahana Press.

Marzuki. (2015). Moral agama. Sebuah pengantar memahami hubungan antara agama dan moralitas. Yogyakarta: UNY Press.

Miftahuddin, \& Kuncorowati, P.W. (2018). Pengembangan modul pendidikan karakter kebangsaan Pancasila di sekolah menengah pertama berbasis pesantren. Jurnal Civics: Media Kajian Kewarganegaraan, 15(2), 134-140. DOI: $10.21831 /$ jc.v15i2.20134.

Mulyasa. (2011). Manajemen pendidikan karakter. Jakarta: PT Bumi Aksara.

Murdiono, dkk. (2017). The education of the national character of Pancasila in secondary school based on pesantren. Cakrawala Pendidikan: Jurnal Ilmiah Pendidikan, 36(3), 423-434. DOI: 10.21831/cp.v36i3.15399.

Naim, N. (2012). Character building optimalisasi peran pendidikan dalam pengembangan ilmu $\mathcal{E}$ pembentukan karakter bangsa. Yogyakarta: Ar-Ruzz Media. 
Humanika, Kajian IImiah Mata Kuliah Umum, Vol. 20. No. 1. (2020), 45-62

Prastowo, A. (2012). Metode penelitian kualitatif dalam perspektif rancangan penelitian. Yogyakarta: Ar-Ruzz Media.

Qamar, M. (2007). Pesantren dari transformasi metodologi menuju demokratisasi institusi. Jakarta: Erlangga.

Rohman, A. (2009). Memahami pendidikan $\mathcal{E}$ ilmu pendidikan. Yogyakarta: LaksBang Mediatama.

Shofiyyah, N.A., Ali, H., \& Sastraatmana, N. (2019). Model pondok pesantren di era milenial. Belajea: Jurnal Pendidikan Islam, 4(1), 1-18 DOI: 10.29240/ belajea.v4i1.585.

Sista dkk. (2019). The implementation of Islamic education in student moral guidance on traditional and modern pesantren institution. International Journal of Social Sciences, 4(3), 1319-1338. DOI: 10.20319/ pijss.2019.43.13191338.

Ubaedillah, A. (2015). Pendidikan kewarganegaraan (civic education): Pancasila, demokrasi, $\mathbb{E}$ pencegahan korupsi. Jakarta: Prenadamedia Group.

Undang-Undang Nomor 20 Tahun 2003 tentang Sistem Pendidikan Nasional.

Wibowo, A. (2012). Pendidikan karakter strategi membangun karakter bangsa berperadaban. Yogyakarta: Pustaka Pelajar. 